\title{
Morphological and Immunohistochemical Features of Malignant Vascular Tumors with Special Emphasis on GLUT1, and FKBP12 Expressions
}

\author{
Malign Vasküler Tümörlerin Morfolojik ve İmmünohistokimyasal \\ Özellikleri ile GLUT1 ve FKBP12 Ekspresyonlarının Vurgulanması
}

\author{
Kemal KÖSEMEHMETOĞLU, Gökhan GEDiKOĞLU, Şevket RUACAN
}

Department of Pathology, Hacettepe University, Faculty of Medicine, ANKARA, TURKEY

\section{ABSTRACT}

Objective: Angiosarcomas and hemangioendotheliomas are rare malignant vascular neoplasms (MVTs). Here, we reviewed the clinicomorphological characteristics of 27 MVTs with the implementation of two novel immunohistochemical markers: GLUT1, and FKBP12.

Material and Method: MVTs, except for Kaposi's sarcoma, were retrieved from the archive and reviewed. Tumor size, the presence of hemorrhage and necrosis, growth pattern, cellularity, cellular characteristics and mitotic activity were recorded as morphological variables. Immunohistochemically, CD34, CD31, GLUT1, FKBP12, Mdm2, p53, c-kit, and CD99 were applied. Clinical information was gathered from hospital records and computer-based patient data systems.

Results: The median age was 53 years (range 16-77). Extremities (37\%) were the most common primary site followed by the head and neck. Five of $16(31 \%)$ low grade and 7 of $11(64 \%)$ high grade tumors were metastasized to varying organs, mainly the liver and lungs. The median survival was 49 months. Ninety percent of high grade tumors were larger than $3 \mathrm{~cm}$. Hemorrhage and necrosis were seen in $85 \%$ and $41 \%$ of cases, respectively. Nuclear pleomorphism, cellularity and mitotic activity were higher in high grade tumors than in low grade ones $(\mathrm{p}<0.0001)$. While $68 \%$ of the cases expressed CD34, $81 \%$ of them were positive with CD31. All cases except one low grade tumor were strongly and diffusely stained with FKBP12. Significant GLUT1 expression was observed in $23 \%$ of cases, especially in areas showing epithelioid morphology. Either Mdm2 or p53 was positive in over one third of the tumors.

Conclusion: The studied markers were not able to distinguish between low and high grade MVTs. FKBP12 may take a role in the diagnostic panel of MVTs. GLUT1 expression, previously proposed for the diagnosis of infantile hemangioma, should be assessed carefully since almost one quarter of MVTs were also GLUT1 positive.

Key Words: Hemangiosarcoma, Hemangioendothelioma, Vascular neoplasms, Immunohistochemistry, GLUT1, FKBP12

\section{ÖZ}

Amaç: Angiosarkomlar ve hemangioendotelyomlar nadir görülen malign vasküler tümör (MVT)'lerdir. Bu çalıșmada, 27 MVT'ün klinikomorfolojik özellikleri incelendi, GLUT1 ve FKBP12 ekspresyonu araştırıldı.

Gereç ve Yöntem: Kaposi sarkom dıșındaki MVT'ler arşivden çıkarıldı ve tekrar incelendi. Tümör çapı, kanama ve nekroz varlığı, büyüme paterni, sellülerite, sellüler karakteristikler ve mitotik aktivite morfolojik değişkenler olarak kaydedildi. İmmünohistokimyasal olarak CD34, CD31, GLUT1, FKBP12, Mdm2, p53, c-kit ve CD99 çalışıldı. Klinik veriler hastane kayıtlarından ve bilgisayar destekli hasta veri tabanından elde edildi.

Bulgular: Hastaların medyan yaşı 53 (aralık 16-77) idi. MVT en sık ekstremitelerde (\%37) ve bunu takiben baş-boyun bölgesinde görülmekteydi. 16 düşük dereceli tümörün 5’i (\%31) ve 11 yüksek dereceli tümörün 7'sinde (\%64) çeşitli organlara, çoğunlukla da karaciğer ve akciğere metastaz tespit edildi. Medyan sağ kalım 49 aydı. Yüksek dereceli tümörlerin \%90'ı 3 cm'den büyüktü. Olguların \%85'inde kanama, \%41'inde ise nekroz izlendi. Düșük dereceli tümörlere kıyasla yüksek dereceli tümörlerde nükleer pleomorfizm, artmış selülerite ve mitotik aktivite daha fazlaydı $(\mathrm{p}<0,0001)$. Olguların \%88'i CD34, \%81'i de CD31 ile pozitifti. Bir düșük dereceli tümör haricinde tüm vakalar FKBP12 ile yaygın ve kuvvetli boyanma gösterdi. Olguların \%23'ünde özellikle epitelioid alanlarda anlamlı GLUT1 ekspresyonu gözlendi. Tümörlerin üçte birinden fazlasında Mdm2 ya da p53 pozitifti.

Sonuç: $\mathrm{Bu}$ araştırmada uygulanan belirteçler düşük ve yüksek dereceli MVT ayırımında başarılı değildir. FKBP12, MVT'lerin immünohistokimyasal tanı panelinde yer alabilir. Bu araştırmada uygulanan belirteçler düşük ve yüksek dereceli MVT ayırımında başarılı değildir. FKBP12, MVT'lerin immünohistokimyasal tanı panelinde yer alabilir. Daha önce infantil hemangiomlarda ekspresyonu gösterilmiş olan GLUT1, MVT’lerin yaklaşık dörtte birinde de pozitif olduğundan, dikkatli bir şekilde yorumlanmalıdır.

Anahtar Sözcükler: Hemanjiyosarkom, Hemanjiyoendotelyom, Vasküler neoplazmlar, İmmünohistokimya, GLUT1, FKBP12

Correspondence: Kemal KÖSEMEHMETOĞLU

Department of Pathology, Hacettepe University, Faculty of Medicine,

ANKARA, TURKEY

E-mail: dokemal@hotmail.com Phone: +90 3122914530 


\section{INTRODUCTION}

Malignant vascular tumors (MVTs), mainly composed of angiosarcoma (AS) and hemangioendothelioma (HE), are considered one of the rarest soft tissue neoplasms in contrast to their benign counterparts. Due to their rarity, information about and experience of MVTs are limited. AS represents the high grade form of MVTs, whereas $\mathrm{HE}$ is regarded as a borderline tumor owing to its better prognosis. Morphological discrimination of these two entities is therefore crucial for the determination of the prognostic outcome of the patients. Although several immunohistochemical markers are suggested to assist in the differentiation of HE from AS, evaluation of morphological characteristics such as size, cellularity, nuclear pleomorphism, necrosis and mitotic activity is still essential for an accurate diagnosis (1).

MVTs showing variable morphologic characteristics may be misdiagnosed as carcinomas or epithelioid sarcoma, especially when epithelioid morphology dominates. In order to overcome this diagnostic difficulty, pathologists widely use immunohistochemistry as a unique ancillary tool, since diagnostic molecular data about MVTs are still unknown and not helpful in this situation. The commonly used immunohistochemical panel includes CD31 and CD34 which lack adequate sensitivity and specificity, especially in tumors with epithelioid morphology (2-5). Recently, some studies have proposed new markers such as FLI1 (6) and FKBP12 (7) for vascular differentiation. Similarly, GLUT1 was introduced as a specific marker for infantile hemangiomas which may mimic MVTs (8). These markers led pathologists to classify vascular tumors more accurately; however, there are a few studies systematically assessing the value of these markers in AS and HE, GLUT1 and FKBP12, to name but two.

In this study, we present the clinicomorphological and immunohistochemical properties of 27 MVTs with special emphasis on GLUT1 and FKBP12 expressions. Although Kaposi's sarcoma is also classified as a malignant vascular neoplasm, there are contradictory data about the vascular origin and differentiation of this tumor. Moreover, it represents a distinct clinical and pathological phenomenon, deviating from the AS and HE spectrum. Kaposi sarcomas are therefore not included in this study.

\section{MATERIAL and METHOD}

\section{Clinical data and tissues}

We collected 11 angiosarcoma (AS) and 16 hemangioendothelioma (HE) cases from the archives between the years 1982 and 2007. Slides were retrieved from the archive and reviewed by two pathologists. Diagnoses of MVTs were made according to Enzinger \& Weiss' diagnostic criteria (1). In some cases, additional immunohistochemical workup was performed to reach the correct diagnosis. For simplicity, HE and AS were regarded as low grade and high grade MVTs, respectively. Tumor size, presence of hemorrhage and necrosis, growth pattern, cellularity, cellular characteristics and mitotic activity were recorded as morphological variables. Clinical data such as possible etiology, age at diagnosis, sex, type and duration of symptoms, tumor site, treatment modalities, and status of patient were recalled from hospital records.

\section{Immunohistochemistry}

After a review of the slides, representative sections were selected and paraffin blocks or unstained sections of 26 cases were available for immunohistochemical study. An immunohistochemical panel composed of CD34, CD31, GLUT1, FKBP12, Mdm2, p53, c-kit and CD99, was titrated for each antibody using appropriate control blocks and relevant concentrations were achieved, as shown in Table I. Immunostainings were performed on formalin-fixed, paraffin-embedded, $4 \mu \mathrm{m}$ thick sections, using standard procedures. After deparaffinization and appropriate antigen retrieval, the sections were incubated with a primary antibody according to instructions in data sheet and then processed by biotinylated goat antimouse antibodies followed by streptavidin conjugated to horseradish peroxidase (UltraTek HRP Anti-Polyvalent Alb Pack, ScyTek) with the use of diaminobenzidine as the chromogen (DakoCytomation).

The expression pattern of each antibody was assessed regarding location (either cytoplasmic or nuclear), intensity and extent. For the assessment of intensity and the extent of staining, cases were categorized into 3 -tier $(+,++,+++)$ groups and the percentage of cells stained was noted. Cutoff level for both p53 and mdm2 expressions was $20 \%$ of cells with $\geq 2+$ positivity.

\section{Statistics}

Chi square and Mann-Whitney $U$ tests were used and $\mathrm{p}<0.05$ was accepted as significant. Binary logistic regression analysis was used in order to reveal independent factors determining grade. In each case, all variables achieving statistical significance at a level of 0.10 in the univariate analysis were considered in the multiple models, and a backward variable selection procedure with $\mathrm{p}$ value cutoff at 0.05 was carried out. Analyses were performed with SPSS for Windows (Version 15.0.0). 
Table I: Dilution and sources of antibodies

\begin{tabular}{|l|l|l|}
\hline Antibody & Source & Clone and concentration \\
\hline CD34 & Neomarkers, LabVision, CA, USA & monoclonal (clone: QBEnd/10), 1:200 \\
\hline CD31 & Neomarkers, LabVision, CA, USA & monoclonal (clone: JC/70A), 1:25 \\
\hline GLUT1 & Neomarkers, LabVision, CA, USA & polyclonal, 1:50 \\
\hline FKBP12 & Alexis Biochemicals, CA, USA & polyclonal, 1:500 \\
\hline Mdm2 & Neomarkers, LabVision, CA, USA & monoclonal (clone: SMP14), 1:50 \\
\hline p53 & Neomarkers, LabVision, CA, USA & monoclonal (clone: SP5), 1:50 \\
\hline c-kit & Neomarkers, LabVision, CA, USA & polyclonal, 1:100 \\
\hline CD99 & Neomarkers, LabVision, CA, USA & monoclonal (clone: HO36-1.1), 1:100 \\
\hline
\end{tabular}

\section{RESULTS}

\section{Clinical characteristics}

Clinical findings are summarized in Table II. Age at diagnosis ranged between 16-77 years with a median of 53. Mass and pain were the two most common symptoms, followed by bleeding and jaundice. The preoperative duration of symptoms ranged from 1 month to 2 years. Extremities (37\%), the most common primary site, were followed by the head and neck, vertebrae, parenchymal organs (liver, colon, and spleen), abdominal wall and breast. Five of the 11 tumors involving the extremities were located at the upper extremities and 6 at the lower extremities. The tumors were located at the extremities in all patients younger than 20 years of age (3 cases).

Eight of 20 patients - 5 with high grade tumors (AS) - had local recurrences. Five of 16 (31\%) HE and 7 of 11 (64\%) AS cases metastasized to varying organs of which the liver and lungs predominated. One patient with AS of the leg had metastasis to the inguinal lymph node and adrenal gland.

Data for treatment protocols were available for 20 patients. Complete surgical removal of the tumor was aimed at in all cases except one. The surgical margins were infiltrated by tumor in 3 cases of AS. Most of the patients received either chemotherapy or radiotherapy after surgical intervention.

Nineteen of 27 (70\%) patients had follow-ups ranging from 1 month to 120 months (median, 36 months, Table III). Five patients, 4 of whom had low grade tumors, were alive for at least 5 years, whereas 9 cases, 5 of which had high grade tumors, died within 40 months. The median survival time was 49 months.

Lymphedema, vascular stent application, radiation and chemical exposure (dye) were considered as possible etiologic factors in 5 patients. Radiotherapy was given due to squamous cell carcinoma of the head and neck, one year before AS was diagnosed in one patient. Another patient with AS of the right upper arm had a history of lumpectomy and axillary dissection due to a breast carcinoma 8 years earlier, and the case was accompanied by lymphangiomatosis, morphologically. A history of vascular operation and stent replacement was recorded in 2 patients. One patient was a painter and chemical exposure was therefore suspected.

\section{Morphological findings}

After a total reexamination of all 27 vascular tumors, 11 of them were categorized as high grade MVT (AS) and 16 were classified as low grade MVT (HE). Details of the morphological findings are given in Table IV.

Macroscopically, tumor size varied from $1 \mathrm{~cm}$ to $20 \mathrm{~cm}$ in diameter (median $6 \mathrm{~cm}$ ) and was $\geq 3 \mathrm{~cm}$ in 18 cases, 10 of which were high grade (Figure 1). The vast majority (10/11) of AS cases was sized $\geq 3 \mathrm{~cm}$ and 8 of 11 cases were also larger than $5 \mathrm{~cm}$ (Table IV). Half of the low grade vascular tumors were also larger than $3 \mathrm{~cm}$.

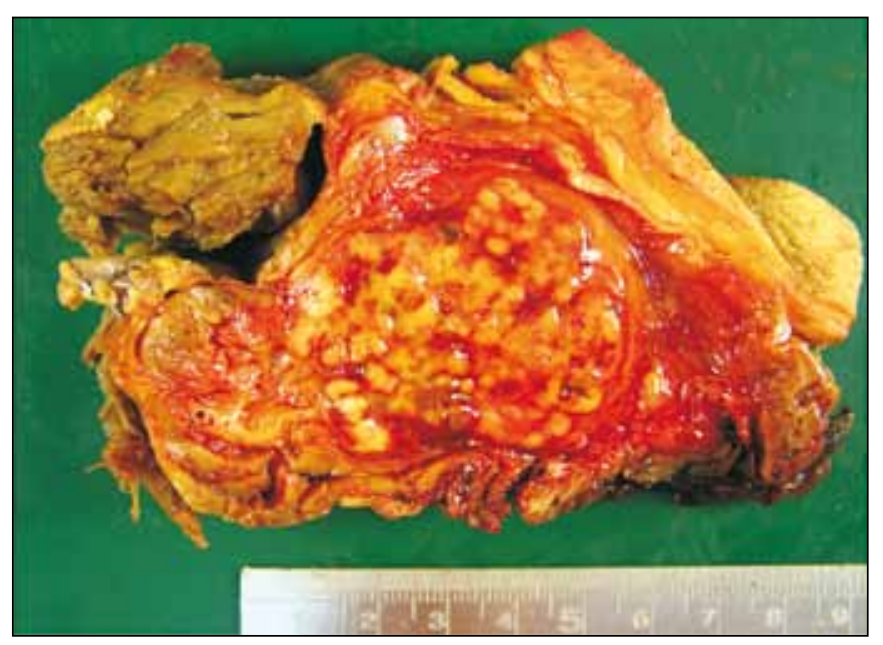

Figure 1: A $5 \mathrm{~cm}$ diameter epithelioid angiosarcoma located at the thigh. 
Table II: Clinical characteristics of MVTs

\begin{tabular}{|c|c|c|c|}
\hline & $\begin{array}{l}\text { Angiosarcoma } \\
\quad(11 \text { cases })\end{array}$ & $\begin{array}{l}\text { Hemangioendothelioma } \\
\text { (16 cases) }\end{array}$ & $\begin{array}{c}\text { Total } \\
(27 \text { cases })\end{array}$ \\
\hline Age & $\begin{array}{c}20-77 \text { years } \\
\text { (median }=54 \text { years) }\end{array}$ & $\begin{array}{c}16-71 \text { years } \\
\text { (median=43 years) }\end{array}$ & $\begin{array}{c}16-77 \text { years } \\
\text { (median }=53 \text { years) }\end{array}$ \\
\hline Gender (M/F) & $5 / 6$ & $9 / 7$ & $14 / 13$ \\
\hline $\begin{array}{l}\text { Tumor site } \\
\text { Extremities } \\
\text { Head and neck } \\
\text { Sacrum } \\
\text { Vertebrae } \\
\text { Liver } \\
\text { Colon } \\
\text { Breast } \\
\text { Spleen } \\
\text { Abdominal wall } \\
\text { Inguinal }\end{array}$ & $\begin{array}{l}6(55 \%) \\
2(18 \%) \\
1(9 \%) \\
1(9 \%) \\
1(9 \%)\end{array}$ & $\begin{array}{l}4(25 \%) \\
3(19 \%) \\
3(19 \%) \\
1(6 \%) \\
2(13 \%) \\
1(6 \%) \\
1(6 \%) \\
1(6 \%)\end{array}$ & $\begin{array}{r}10(37 \%) \\
5(18 \%) \\
3(11 \%) \\
2(7 \%) \\
2(7 \%) \\
1(4 \%) \\
1(4 \%) \\
1(4 \%) \\
1(4 \%) \\
1(4 \%)\end{array}$ \\
\hline $\begin{array}{l}\text { Presenting symptoms } \\
\text { Mass } \\
\text { Pain } \\
\text { Bleeding } \\
\text { Jaundice }\end{array}$ & $\begin{array}{l}6(55 \%) \\
5(45 \%)\end{array}$ & $\begin{array}{l}9(57 \%) \\
4(25 \%) \\
2(12 \%) \\
1(6 \%)\end{array}$ & $\begin{array}{c}15(55 \%) \\
8(30 \%) \\
2(7 \%) \\
1(4 \%)\end{array}$ \\
\hline $\begin{array}{l}\text { Metastasis * } \\
\text { Lung } \\
\text { Liver } \\
\text { Bone } \\
\text { Lymph node } \\
\text { Brain } \\
\text { Adrenal }\end{array}$ & $\begin{array}{l}7 / 11(64 \%) \\
4 \\
3 \\
1 \\
1 \\
1\end{array}$ & $\begin{array}{l}5 / 16(31 \%) \\
2 \\
4 \\
2 \\
1\end{array}$ & $\begin{array}{l}12 / 27(44 \%) \\
6 \\
7 \\
3 \\
1 \\
1 \\
1\end{array}$ \\
\hline $\begin{array}{l}\text { Treatment } \\
\text { Surgery } \\
\text { C } \\
\text { Surgery + C } \\
\text { Surgery + R } \\
\text { Surgery + C + R } \\
\text { Unknown }\end{array}$ & $\begin{array}{l}1 \\
0 \\
2 \\
2 \\
4 \\
2\end{array}$ & $\begin{array}{l}3 \\
1 \\
2 \\
1 \\
3 \\
6\end{array}$ & $\begin{array}{l}4 \\
1 \\
4 \\
3 \\
7 \\
8\end{array}$ \\
\hline
\end{tabular}

${ }^{*}$ Multiple metastatic sites may present in a single patient

C; chemotherapy, R; radiotherapy

Table III: Comparison of status of patients and tumor grade in 19 cases having available follow-up information

\begin{tabular}{|c|c|c|c|}
\hline \multirow{2}{*}{$\begin{array}{c}\text { Disease } \\
\text { status }\end{array}$} & \multirow{2}{*}{$\begin{array}{c}\text { No of } \\
\text { patients }\end{array}$} & $\begin{array}{c}\text { Low grade } \\
\text { (HE) }\end{array}$ & $\begin{array}{c}\text { High grade } \\
\text { (AS) }\end{array}$ \\
\hline DOD & $9(47 \%)$ & 4 & 5 \\
\hline NED & $5(26 \%)$ & 4 & 1 \\
\hline AWD & $5(26 \%)$ & 2 & 3 \\
\hline
\end{tabular}

AWD; alive with disease, DOD; dead of disease, NED; alive and no evidence of disease, AS; angiosarcoma, HE; hemangioendothelioma
On microscopy, the majority of lesions were hemorrhagic (85\%) and necrosis was found in $41 \%$ of cases, mainly in high grade tumors. An infiltrative pattern was seen in 16 of 24 cases, while expansive growth was dominant in 8 of 24 . In 3 cases a growth pattern could not be assessed because of the limited sampling.

High nuclear pleomorphism, cellularity and mitotic activity were found to be independent factors favoring the diagnosis of high grade malignancy on multivariate analysis $\left(\mathrm{R}^{2}=0.75, \mathrm{p}<0.0001\right)$. The mitotic count was significantly 
Table IV: Morphological features of MVTs

\begin{tabular}{|c|c|c|c|}
\hline & $\begin{array}{l}\text { Angiosarcoma } \\
\text { (11 cases) }\end{array}$ & $\begin{array}{l}\text { Hemangioendothelioma } \\
\text { (16 cases) }\end{array}$ & $\begin{array}{c}\text { Total } \\
\text { (27 cases) }\end{array}$ \\
\hline $\begin{array}{l}\text { Tumor size } \\
\qquad 3 \mathrm{~cm} \\
<3 \mathrm{~cm} \\
\text { Unknown }\end{array}$ & $\begin{array}{c}2-10 \mathrm{~cm}(\text { median }=6 \mathrm{~cm}) \\
10(91 \%) \\
1(9 \%)\end{array}$ & $\begin{array}{c}1-20 \mathrm{~cm}(\text { median }=3 \mathrm{~cm}) \\
8(50 \%) \\
6(38 \%) \\
2(12 \%) \\
\end{array}$ & $\begin{array}{c}1-20 \mathrm{~cm}(\text { median }=5.5 \mathrm{~cm}) \\
18(66 \%) \\
7(26 \%) \\
2(7 \%)\end{array}$ \\
\hline Presence of necrosis & $5 / 11$ & $6 / 16$ & $11 / 27$ \\
\hline Presence of hemorrhage & $10 / 11$ & $13 / 16$ & $23 / 27$ \\
\hline $\begin{array}{l}\text { Cellular characteristics } \\
\text { Epithelioid dominant } \\
\text { Spindle dominant }\end{array}$ & $\begin{array}{l}9 \\
2\end{array}$ & $\begin{array}{l}8 \\
8\end{array}$ & $\begin{array}{l}17 \\
10\end{array}$ \\
\hline $\begin{array}{l}\text { Pleomorphism } \\
\text { High } \\
\text { Intermediate } \\
\text { Low }\end{array}$ & $\begin{array}{l}8 \\
2 \\
1\end{array}$ & $\begin{array}{r}1 \\
2 \\
13\end{array}$ & $\begin{array}{r}9 \\
4 \\
14\end{array}$ \\
\hline $\begin{array}{l}\text { Cellularity } \\
\qquad \begin{array}{l}1+ \\
2+ \\
3+\end{array}\end{array}$ & $\begin{array}{r}0 \\
1 \\
10\end{array}$ & $\begin{array}{l}5 \\
8 \\
3\end{array}$ & $\begin{array}{r}5 \\
9 \\
13\end{array}$ \\
\hline
\end{tabular}

${ }^{\star}$ In cases that could be assessed.

HPF; high power field (x400)

Table V: Immunohistochemical findings in MVTs

\begin{tabular}{|c|c|c|c|c|c|c|c|c|c|c|}
\hline & \multicolumn{4}{|c|}{ CD34 $(n=25)$} & \multicolumn{4}{|c|}{ CD31 $(n=26)$} & \multirow{2}{*}{$\begin{array}{c}\text { FKBP12 } \\
(n=25)\end{array}$} & \multirow{2}{*}{$\begin{array}{l}\text { GLUT1 } \\
(\mathrm{n}=26)\end{array}$} \\
\hline & Neg. & Low & Int. & High & Neg. & Low & Int. & High & & \\
\hline HE & $2 / 14$ & $0 / 14$ & $4 / 14$ & $8 / 14$ & $2 / 15$ & $0 / 15$ & $4 / 15$ & $9 / 15$ & $13 / 14$ & $2 / 15$ \\
\hline AS & $5 / 11$ & $1 / 11$ & $1 / 11$ & $4 / 11$ & $0 / 11$ & $3 / 11$ & $3 / 11$ & $5 / 11$ & $11 / 11$ & $4 / 11$ \\
\hline Total & $7 / 25$ & $1 / 25$ & $5 / 25$ & $12 / 25$ & $2 / 26$ & $3 / 26$ & $7 / 26$ & $14 / 26$ & $24 / 25$ & $6 / 26$ \\
\hline
\end{tabular}

Neg; negative, Int; intermediate, HE; hemangioendothelioma, AS; angiosarcoma

higher in AS than in HE $(\mathrm{p}<0.0001)$. Presence of neither hemorrhage nor necrosis was associated with the grade. The occurrence of metastasis was almost significantly predicted by high mitotic activity $(\mathrm{p}=0.061)$ and expansile growth pattern $(\mathrm{p}=0.066)$ in multivariate analysis $\left(\mathrm{R}^{2}=33.4\right)$

\section{Immunohistochemical findings}

Twenty-six cases were available for immunohistochemical study. In order to evaluate the expression of CD34 and
CD31, 4 groups were formed regarding intensity and extent: negative, low, intermediate and high. For example; $2+$ in $20 \%$ of the cells was grouped as intermediate; $2+$ in $50 \%$ of the cells was included in the high expression group. 68\% and $81 \%$ of cases expressed CD34 and CD31, respectively (Figure 2). All cases were diffuse and/or strongly positive either with CD34 or CD31, but one showed focal weak expression with both. Detailed results are shown in Table V. 


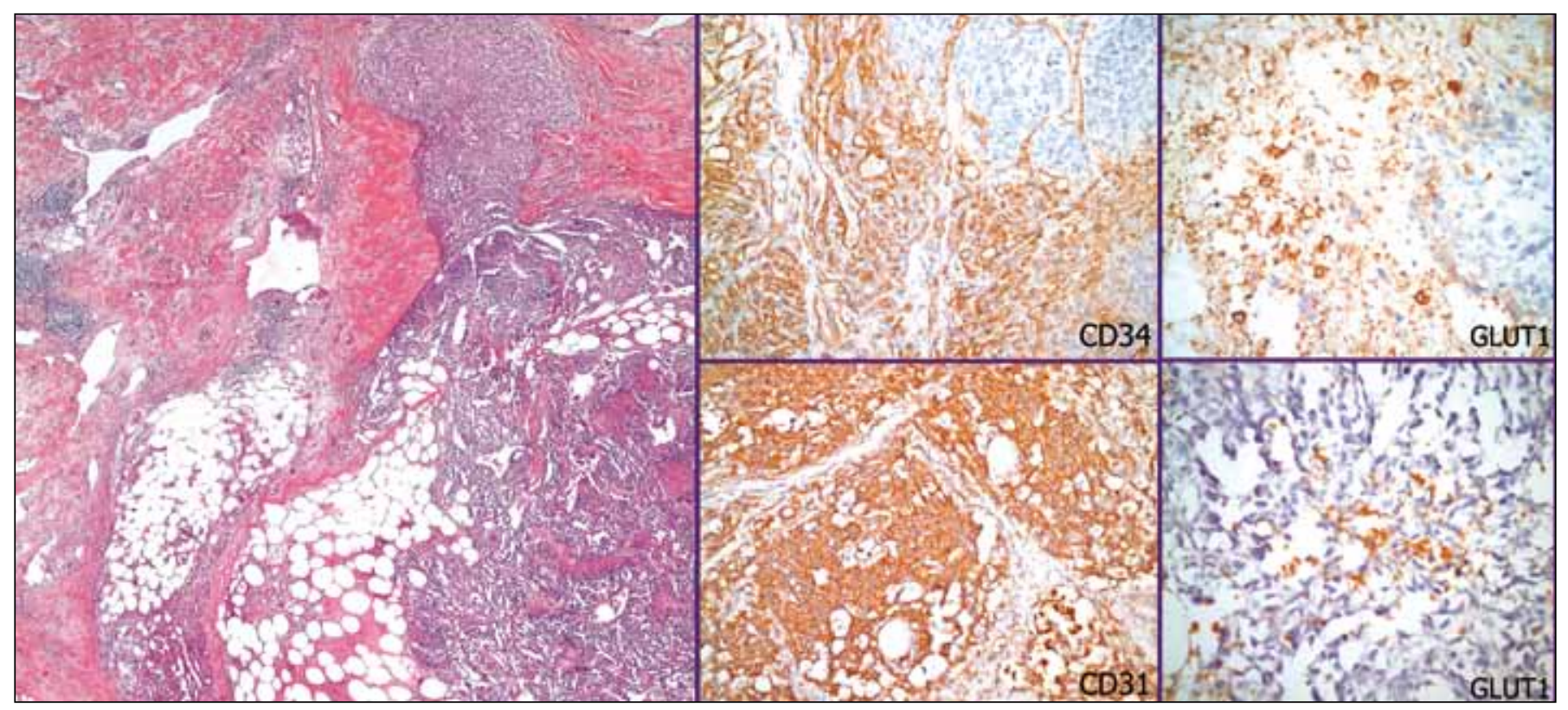

Figure 2: An angiosarcoma with infiltrative borders containing both epithelioid and vasoformative (lower grade) areas (H\&E; $\mathrm{x} 40$ ). Both CD34 and CD31 were strongly positive (x200). GLUT1 expression was more prominent in epithelioid cells than cells forming welldifferentiated vascular channels (x400). Erythrocytes showed membranous staining as an internal control.

Membranous GLUT1 staining was seen in almost one quarter $(23 \%)$ of the cases at least focally (Figure 2, 3). The intensity of expression was graded relative to the expression strength of internal controls and GLUT1 expression was strong in all positive tumors except one case of HE. As an interesting finding was that GLUT1 expression was stronger in epithelioid cells, while hobnail cells representing retiform areas were GLUT1 negative (Figure 2,3).

All cases showed strong FKBP12 expression except one low grade $\mathrm{HE}$ of the liver diagnosed with needle biopsy and in which expression was weak. In this case, CD34 was also positive, while CD31 was not determined. Diffuse cytoplasmic FKBP12 staining was seen in all cases, with accompanying nuclear staining in 2 cases (Figure 3 ). FKBP12 staining was more pronounced in areas formed by well-differentiated vascular channels than poorly differentiated compartments (Figure 3).

Either Mdm2 or p53 was positive in $34.6 \%$ of the cases (Figure 4): 1) 3 of 11 AS and 2 of 14 HE expressed p53; 2) 3 of $11 \mathrm{AS}$ and 2 of $15 \mathrm{HE}$ were positive for $\mathrm{mdm} 2$; resulting in 5 out of $11(45.5 \%)$ AS positive for either p53 or $\mathrm{mdm} 2$, compared with 4 positive cases out of $15(26.6 \%)$ HE cases. CD99 and c-kit were both negative in all cases. None of the studied markers correlated with survival. The immunohistochemical expression pattern did not vary significantly between low and high grade tumors.

\section{DISCUSSION}

MVTs are rare tumors; little is therefore known regarding the clinicomorphological features and prognosis. Only 27 cases of malignant endothelial tumors were identified in our detailed review of cases between 1980 and 2007. Taking into account their rarity, the diagnosis of MVT is still challenging and needs to be viewed with suspicion although there are some macroscopic (hemorrhage) and microscopic (anatomizing channels) clues in welldifferentiated tumors. The diagnostic challenge peaks when epithelioid morphology predominates. Beyond the diagnostic challenge, deciding on the grade of the tumor, which determines the prognosis, is exclusively troublesome. Moreover, there is still debate on using the term "hemangioendothelioma", a tumor of intermediate malignancy between AS and hemangiomas, since these tumors can be regarded as low grade AS or AS having mixed phenotype $(1,9)$. We found that mainly cellularity, mitotic index and pleomorphism have an impact on the decision of the grade. We believe that HE, which is less cellular and pleomorphic and shows less mitotic activity than AS, represents a morphological continuum or a subset of AS, in other words low grade AS.

HE and AS formed a clinicopathological spectrum as "MVTs" in this study. Both are often seen in the $5-6^{\text {th }}$ decades with no gender difference. Involved sites also shared similar consequences. Patients with AS had more metastasis than 


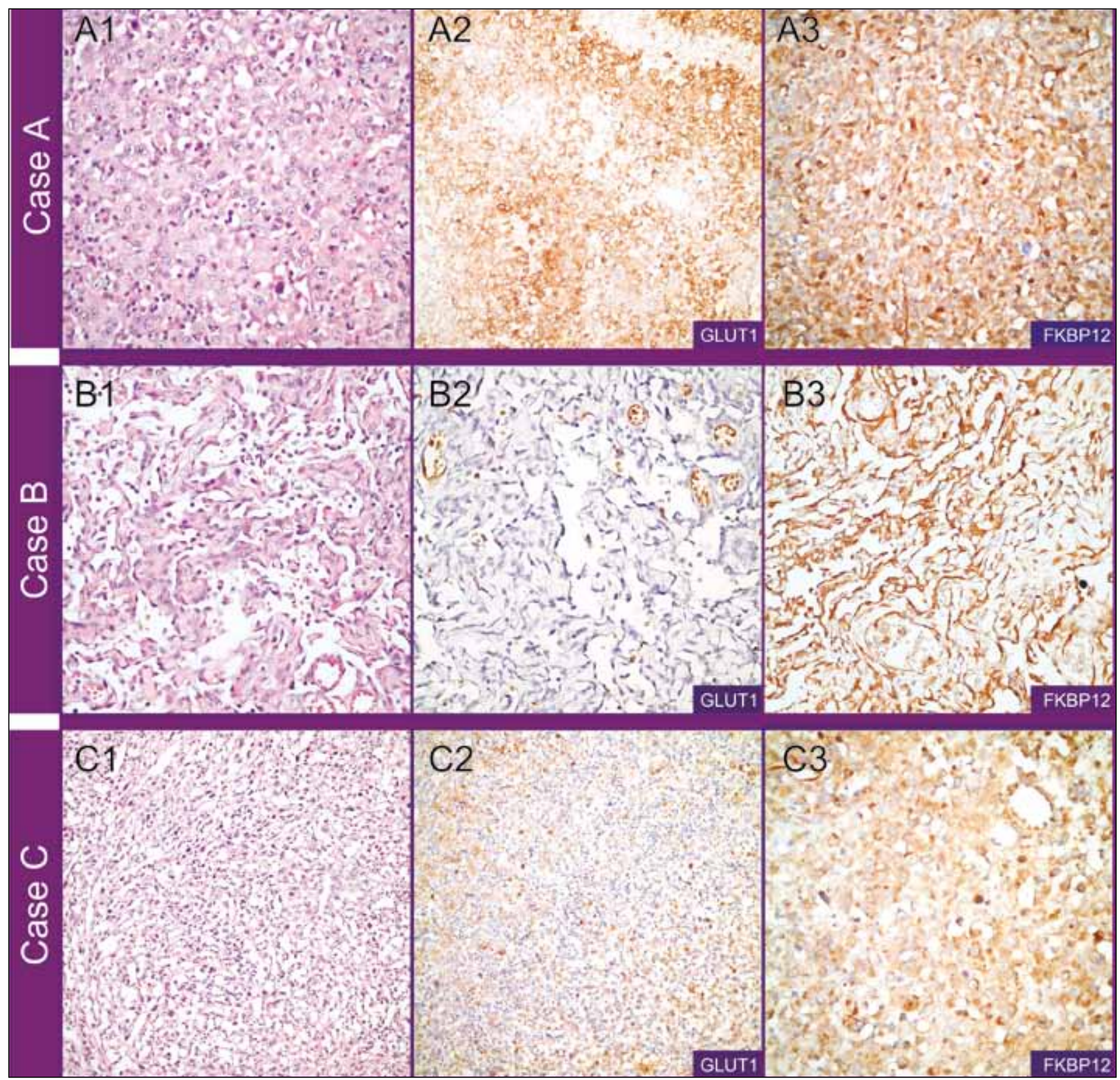

Figure 3: There are three different cases showing constant FKBP12 expression variable staining patterns with GLUT1: Case A diagnosed as epithelioid angiosarcoma revealed strong GLUT1 expression (A1, A2; x200). Diffuse cytoplasmic and focal nuclear FKBP12 positivity are seen (A3; x200). In case B, the diagnosis was retiform hemangioendothelioma, characterized with vascular channels lined by hobnail nuclei with minimal atypia (B1, x100). GLUT1 expression is not seen in these cells (B2; x100). However, FKBP12 showed diffuse reactivity (B3; x100). Case 3 represents an angiosarcoma with vasoformative areas but high nuclear atypia (C1; x100). Neoplastic cells displayed focal but strong GLUT1 expression (C2; x100). FKBP12 was also positive (C3; x100). 


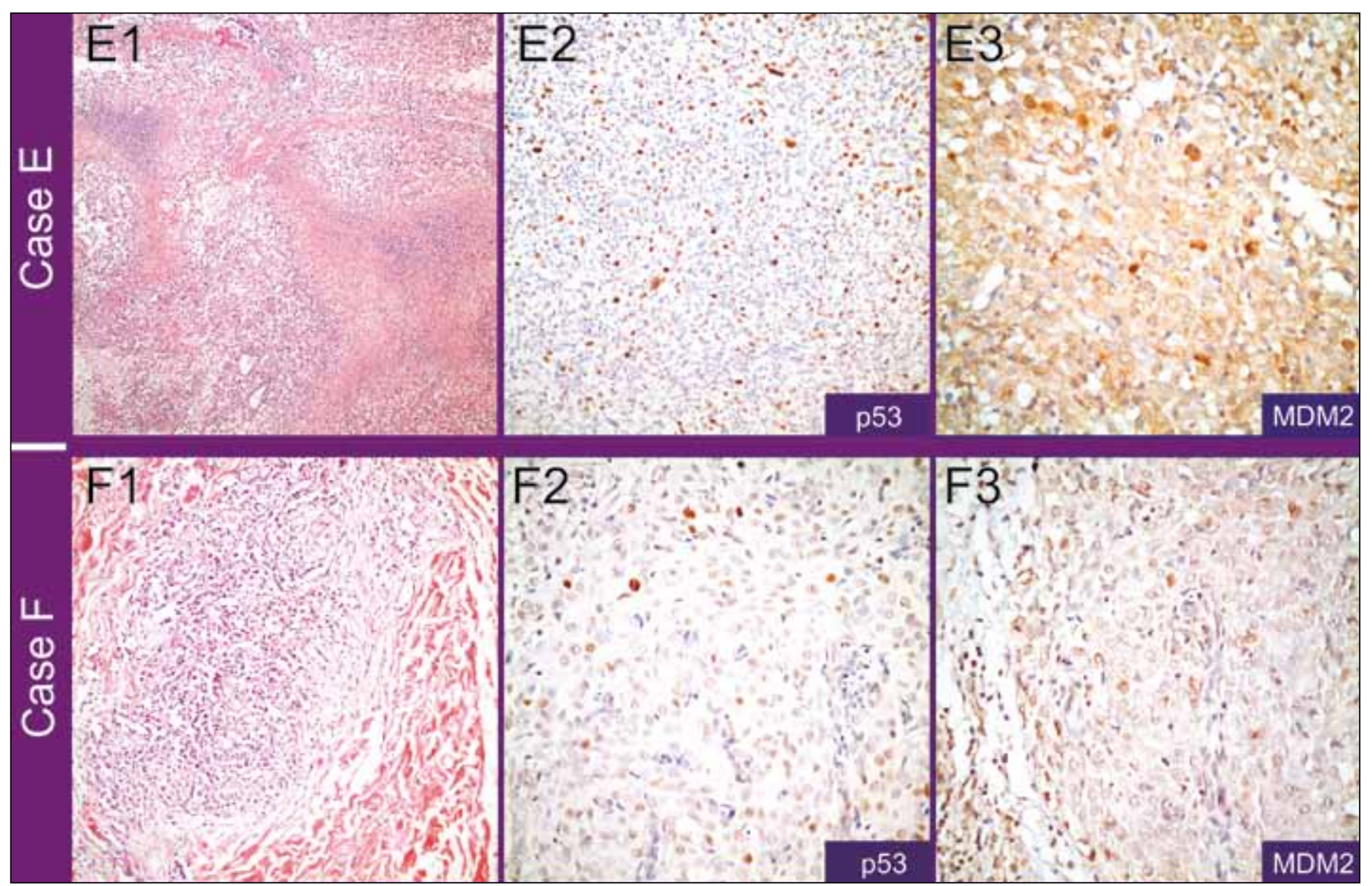

Figure 4: Two cases showing p53 and Mdm2 positivity together (E1; H\&E, x40, E2; p53, x100, E3; Mdm2, x200, F1; H\&E, x100, F2; p53, x200, F3; Mdm2, x200).

patients with HE, as can be expected; however, almost the same number of cases of HE and AS had died of disease among the patients for whom the follow-up information was available, despite vigorous therapy. Nonetheless, 4 out of 5 patients who had no evidence of disease for at least 4 years were diagnosed as HE. In an early study of 30 patients diagnosed as epithelioid HE, the metastatic rate was $21 \%$ and $17 \%$ had progressed to death. The authors concluded that it was not possible to distinguish between epithelioid HE and AS (10). Recently, Deyrup et al. (9) reported that $22 \%$ of epithelioid HE metastasized and $18 \%$ of patients died of disease depending on mitotic activity and the size of tumor. Tumors larger than $3 \mathrm{~cm}$ and with mitotic activity higher than 3 mitoses/50 high power fields (HPF) had the worst prognosis. It has been suggested that this unpredictable outcome of HE may be due to the alterations in gene expression pattern in low grade vascular tumor resulting in an upgrade to AS (11). Morphologically, HE displays a more infiltrative pattern with less mitosis and pleomorphism than AS, which is mostly larger than 3 $\mathrm{cm}$, clearly pleomorphic and has a higher mitotic index.
Necrosis can be seen in both conditions; hence, one should not make diagnosis of AS depending on the presence of necrosis. Many etiologic factors, such as chemicals (Thorotrast, vinyl chloride, chemotherapeutics), radiation, lymphedema, pyothorax and vascular stents, were reported to cause MVTs (12). Indeed, many of these (lymphedema, chemical exposure, vascular stent and radiation) were also investigated in our series.

18F-FDG PET imaging has been applied for staging of various tumors for a decade. It has been shown that intracellular transportation of 18F-FDG mediated by GLUT receptors is a key factor for tissue accumulation of 18F-FDG. Since the metabolic activity of tumors is usually accepted as a determinant of the biological behavior, GLUT receptor expression status may have an influence on the prognosis. However, there are controversial data about GLUT1 expression of tumors and 18F-FDG uptake. Some studies showed a strong correlation between GLUT1 expression and 18F-FDG uptake in various neoplasia, while others were not able to demonstrate this correlation 
(13). Of particular interest, 18F-FDG PET scan has been shown to be a sensitive and specific diagnostic tool for determination of malignant change in plexiform neurofibromas in neurofibromatosis patients $(14,15)$. However, a morphological study supporting this finding has not been carried out yet.

GLUT1 is an erythrocyte-type glucose transport protein that is expressed in erythrocytes, the blood brain barrier, perineurium, retina, placenta and at low levels in muscle and fatty tissue $(16,18)$. Given that many, if not all, mitogens stimulate GLUT1 transcription, overexpression is shown in many tumors (17-20) correlating with a poor outcome (21-23). Some studies have recently shown that GLUT1 expression is useful for distinguishing benign from malignant lesions, i.e. malignant mesothelioma from reactive mesothelial hyperplasia (24). GLUT1 expression is also thought to be a potential marker for malignant transformation. Sakashita et al. (25) demonstrated that GLUT1 expression was higher in colonic adenomas with high grade dysplasia than adenomas with low grade dysplasia; moreover, GLUT1 overexpression was also shown to be associated with depth of invasion, morphological type and histological differentiation status of colon carcinomas, in support of previous papers $(26,27)$. In a recent study, Ahrens et al. (28) demonstrated widespread GLUT-1 expression in many mesenchymal neoplasms and concluded that the diagnostic uses of GLUT-1 in the evaluation of mesenchymal neoplasms are quite limited. However, specific GLUT1 expression has been demonstrated in juvenile hemangiomas and intramuscular hemangiomas $(8,29$, 30) among vascular neoplasms, both of which represent benign vascular tumors. According to those studies, focal GLUT1 expression was reported in 5 out of 14 (35\%) AS, while none of $8 \mathrm{HE}$ cases was stained. Regarding AS, our results $(36 \%$ of AS) are compatible with the findings of North et al.; however, we also observed that $2(13 \%)$ of 15 HE cases expressed GLUT1. Meanwhile, among AS and HE, GLUT1 expression is limited to epithelioid areas instead of well-differentiated retiform or arborising canalicular areas. This may suggest high glucose consumption of poorly differentiated epithelioid areas of both AS and HE, as also suggested by Ahrens et al. (28). Although GLUT1 had a tendency to be overexpressed in AS rather than HE, GLUT1 expression did not significantly correlate with either grade or survival of the cases; this result partly could be explained by the relative small number of positive cases. Thus, further studies with a higher number of cases are needed.

FKBP12 serves as a cytosolic protein receptor for an immunosuppressor agent, FK506 (tacrolimus) and exerts its effect through the inhibition of $\mathrm{Ca} 2+$ and calmodulindependent calcineurin function, regulating $\mathrm{B}$ and $\mathrm{T}$ cell responses (31). FKBP12 is expressed in Hassall's corpuscles, keratinocytes and also endothelium (32). In a microarray study, Higgins et al. (7) proposed that using an immunohistochemical panel, including FKBP12 combined with CD34 and CD31, yields 93\% diagnostic sensitivity among 14 hemangioendotheliomas and 100\% diagnostic sensitivity 11 AS cases. In this study, FKBP12 is expressed in all cases of both low and high grade MVTs and expression was much more remarkable in well differentiated areas. Our findings are consistent with the study of Higgins et al. (7), except for the fact that they observed more prominent nuclear expression. Benign vascular proliferations were also shown to stain positively with FKBP12 (7). Furthermore, FKBP12 was recently found to be an important regulator of vascular endothelial ryanodine receptors, contributing to endothelial function and regulation of blood pressure $(33,34)$. Interestingly, upregulation of FKBP12 protein is observed in neointima formation of in-stent restenosis (35). Our results suggest that upregulation of FKBP12 may play a role in pathogenesis of vascular proliferations. There are no studies showing FKBP12 expression in lymphatic endothelium. Nevertheless, it can be speculated that $\mathrm{HE}$ and AS share the same vascular endothelial origin since FKBP12 expression is found to be universal for both tumors. FKBP12 may take a role as an endothelial marker in the diagnostic immunohistochemical panel, but attention should be paid in poorly differentiated tumors in which FKBP12 expression is weaker.

Dysfunction of the mdm-2/p53 pathway regulating VEGF regulation via thrombomodulin-1 was postulated by Zietz et al. and shown in the two thirds of ASs (36). Naka et al. found that p53 mutation is a major pathway in the occurrence of AS and the frequency of p53 mutations varies with the site of involvement. In a large series, p53 expression in AS was $20 \%$ (3). However, in some cases, mutations in the p53 gene is lacking despite the accumulation of p53 protein that could be explained by another mechanism involving $\mathrm{mdm} 2$ (36). Just over one third of MVTs in our series revealed either p53 or $\mathrm{mdm} 2$ expression. The p53/ mdm2 pathway may contribute to the pathogenesis, at least in some cases.

In summary, $\mathrm{HE}$ and $\mathrm{AS}$ are in the morphological spectrum of MVTs. Therefore, following an algorithm as a consideration of pleomorphism, mitotic activity and cellularity has a key role in determining the grade of MVTs, and thus the diagnosis of AS. The need for more objective findings, such as molecular studies, is still obvious on the 
way to a specific diagnosis of MVTs. FKBP12 may take a role in the diagnostic panel of MVTs. GLUT1, although only expressed in a subset of cases, reveals the epithelioid character of a tumor, which is likely to suggest a worse prognosis. However, these markers were able neither to distinguish between low and high grade MVT nor to remark a significant difference.

\section{ACKNOWLEDGEMENTS}

This study is granted by Hacettepe University Scientific Research Unit, Grant number: 0501101009. Special thanks to Mutlu Hayran, MD for help on statistical inference, Kenan Kösemehmetoğlu and John Duggan for English revision. We thank Ünal Şeref, Şenay Korkmaz, Ziya Birinci and Lokman Kale for their technical assistance.

\section{REFERENCES}

1. Weiss SW, Goldblum JR: Hemangioendothelioma: Vascular Tumors of Intermediate malignancy. In Weiss SW, Goldblum JR (eds): Enzinger and Weiss' soft tissue tumors. 5th ed, St. Louis, Mosby, 2008, 891-915

2. den Bakker MA, Flood SJ, Kliffen M: CD31 staining in epithelioid sarcoma. Virchows Arch 2003, 443: 93-97

3. Meis-Kindblom JM, Kindblom LG: Angiosarcoma of soft tissue: a study of 80 cases. Am J Surg Pathol 1998, 22: 683-697

4. Ohsawa M, Naka N, Tomita Y, Kawamori D, Kanno H, Aozasa $K$ : Use of immunohistochemical procedures in diagnosing angiosarcoma. Evaluation of 98 cases. Cancer 1995, 75: 2867-2874

5. Partanen TA, Alitalo K, Miettinen M: Lack of lymphatic vascular specificity of vascular endothelial growth factor receptor 3 in 185 vascular tumors. Cancer 1999, 86: 2406-2412

6. Folpe AL, Chand EM, Goldblum JR, Weiss SW: Expression of Fli1 , a nuclear transcription factor, distinguishes vascular neoplasms from potential mimics. Am J Surg Pathol 2001, 25: 1061-1066

7. Higgins JP, Montgomery K, Wang L, Domanay E, Warnke RA, Brooks JD, van de Rijn M: Expression of FKBP12 in benign and malignant vascular endothelium: an immunohistochemical study on conventional sections and tissue microarrays. Am J Surg Pathol 2003, 27: 58-64

8. North PE, Waner M, Mizeracki A, Mihm MC, Jr: GLUT1: a newly discovered immunohistochemical marker for juvenile hemangiomas. Hum Pathol 2000, 31: 11-22

9. Deyrup AT, Tighiouart M, Montag AG, Weiss SW: Epithelioid hemangioendothelioma of soft tissue: a proposal for risk stratification based on 49 cases. Am J Surg Pathol 2008, 32: 924-927

10. Mentzel T, Beham A, Calonje E, Katenkamp D, Fletcher CD: Epithelioid hemangioendothelioma of skin and soft tissues: clinicopathologic and immunohistochemical study of 30 cases. Am J Surg Pathol 1997, 21: 363-374

11. Theurillat JP, Vavricka SR, Went P, Weishaupt D, Perren A, Leonard-Meier C, Bachli EB: Morphologic changes and altered gene expression in an epithelioid hemangioendothelioma during a ten-year course of disease. Pathol Res Pract 2003, 199: 165-170
12. Naka N, Ohsawa M, Tomita Y, Kanno H, Uchida A, Aozasa K: Angiosarcoma in Japan. A review of 99 cases. Cancer 1995, 75: 989-996. PMID: 7842420

13. Avril N: GLUT1 expression in tissue and (18)F-FDG uptake. J Nucl Med 2004, 45: 930-932

14. Ferner RE, GoldingJF, Smith M, Calonje E, Jan W, Sanjayanathan V, O'Doherty M: [18F]2-fluoro-2-deoxy-D-glucose positron emission tomography (FDG PET) as a diagnostic tool for neurofibromatosis 1 (NF1) associated malignant peripheral nerve sheath tumours (MPNSTs): a long-term clinical study. Ann Oncol 2008, 19: 390-394

15. Fisher MJ, Basu S, Dombi E, Yu JQ, Widemann BC, Pollock AN, Cnaan A, Zhuang H, Phillips PC, Alavi A: The role of [18F]fluorodeoxyglucose positron emission tomography in predicting plexiform neurofibroma progression. J Neurooncol 2008, 87: $165-171$

16. Gould GW, Holman GD: The glucose transporter family: structure, function and tissue-specific expression. Biochem J 1993, 295: 329-341

17. Kalir T, Rahaman J, Hagopian G, Demopoulos R, Cohen C, Burstein DE: Immunohistochemical detection of glucose transporter GLUT1 in benign and malignant fallopian tube epithelia, with comparison to ovarian carcinomas. Arch Pathol Lab Med 2005, 129: 651-654

18. Macheda ML, RogersS, Best JD: Molecular and cellular regulation of glucose transporter (GLUT) proteins in cancer. J Cell Physiol 2005, 202: 654-662

19. Ozcan A, Shen SS, Zhai QJ, Truong LD: Expression of GLUT1 in primary renal tumors: morphologic and biologic implications. Am J Clin Pathol 2007, 128: 245-254

20. Younes M, Lechago LV, Somoano JR, Mosharaf M, Lechago J: Wide expression of the human erythrocyte glucose transporter Glut1 in human cancers. Cancer Res 1996, 56: 1164-1167

21. Kang SS, Chun YK, Hur MH, Lee HK, Kim YJ, Hong SR, Lee JH, Lee SG, Park YK: Clinical significance of glucose transporter 1 (GLUT1) expression in human breast carcinoma. Jpn J Cancer Res 2002, 93: 1123-1128

22. Kawamura T, Kusakabe T, Sugino T, Watanabe K, Fukuda T, Nashimoto A, Honma K, Suzuki T: Expression of glucose transporter-1 in human gastric carcinoma: association with tumor aggressiveness, metastasis, and patient survival. Cancer 2001, 92: 634-641

23. Kim YW, Park YK, Yoon TY, Lee SM: Expression of the GLUT1 glucose transporter in gallbladder carcinomas. Hepatogastroenterology 2002, 49: 907-911

24. Kato Y, Tsuta K, Seki K, Maeshima AM, Watanabe S, Suzuki K, Asamura H, Tsuchiya R, Matsuno Y: Immunohistochemical detection of GLUT-1 can discriminate between reactive mesothelium and malignant mesothelioma. Mod Pathol 2007, 20 : 215-220

25. Sakashita M, Aoyama N, Minami R, Maekawa S, Kuroda K, Shirasaka D, Ichihara T, Kuroda Y, Maeda S, Kasuga M: Glut1 expression in T1 and T2 stage colorectal carcinomas: its relationship to clinicopathological features. Eur J Cancer 2001, 37: 204-209 
26. Haber RS, Rathan A, Weiser KR, Pritsker A, Itzkowitz SH, Bodian C, Slater G, Weiss A, Burstein DE: GLUT1 glucose transporter expression in colorectal carcinoma: a marker for poor prognosis. Cancer 1998, 83: 34-40

27. Younes M, Lechago LV, Lechago J: Overexpression of the human erythrocyte glucose transporter occurs as a late event in human colorectal carcinogenesis and is associated with an increased incidence of lymph node metastases. Clin Cancer Res 1996, 2: 1151-1154

28. Ahrens WA, Ridenour RV, 3rd, Caron BL, Miller DV, Folpe AL: GLUT-1 expression in mesenchymal tumors: an immunohistochemical study of 247 soft tissue and bone neoplasms. Hum Pathol 2008, 39: 1519-1526

29. Drut R, Altamirano E: Endothelial cells of intramuscular (infantile) hemangioma express glut1. Int J Surg Pathol 2007, 15: 166-168

30. North PE, Waner M, Mizeracki A, Mrak RE, Nicholas R, Kincannon J, Suen JY, Mihm MC Jr: A unique microvascular phenotype shared by juvenile hemangiomas and human placenta. Arch Dermatol 2001, 137: 559-570

31. Liu J, Farmer JD, Jr., Lane WS, Friedman J, Weissman I, Schreiber $S L$ : Calcineurin is a common target of cyclophilin-cyclosporin A and FKBP-FK506 complexes. Cell 1991, 66: 807-815
32. Nishio H, Matsui K, Tsuji H, Tamura A, Suzuki K: Immunolocalization of calcineurin and FKBP12, the FK506binding protein, in Hassall's corpuscles of human thymus and epidermis. Histochem Cell Biol 2000, 114: 9-14

33. Long C, Cook LG, Hamilton SL, Wu GY, Mitchell BM: FK506 binding protein 12/12.6 depletion increases endothelial nitric oxide synthase threonine 495 phosphorylation and blood pressure. Hypertension 2007, 49: 569-576

34. Long C, Cook LG, Wu GY, Mitchell BM: Removal of FKBP12/12.6 from endothelial ryanodine receptors leads to an intracellular calcium leak and endothelial dysfunction. Arterioscler Thromb Vasc Biol 2007, 27: 1580-1586

35. Zohlnhofer D, Klein CA, Richter T, Brandl R, Murr A, Nührenberg T, Schömig A, Baeuerle PA, Neumann FJ: Gene expression profiling of human stent-induced neointima by cDNA array analysis of microscopic specimens retrieved by helix cutter atherectomy: Detection of FK506-binding protein 12 upregulation. Circulation 2001, 103: 1396-1402

36. Zietz C, Rossle M, Haas C, Sendelhofert A, Hirschmann A, Sturzl M, Lohrs U: MDM-2 oncoprotein overexpression, p53 gene mutation, and VEGF up-regulation in angiosarcomas. Am J Pathol 1998, 153: 1425-1433 